\title{
Use Of Outcome Measures To Modernize Curricula
}

J. Patrick McLaughlin, (Email: jpat@mail.nwmissouri.edu), Northwest Missouri State University Jason White, (Email: jwhite@mail.nwmissouri.edu), Northwest Missouri State University

\begin{abstract}
In the current environment in higher education of trying to substantiate and justify that you are doing a great job as a department educating your students to be prepared for the "real world", outcomes assessment is a major player. But as many departments have found, "once you have received the feedback, now what do you do with it?" Our paper will discuss how some of the outcome measurements that we use at Northwest Missouri State University in the Finance discipline become our decision drivers in course content and curricular reformation.
\end{abstract}

\section{INTRODUCTION}

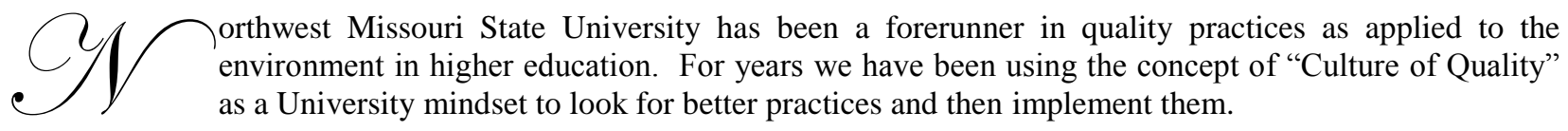

In fact, in 1996 the University central administration began a University-wide planning process known as the Seven-Step Planning Process (or SSPP). Every academic department and administrative office was to develop a "plan" that would incorporate this outline for quality planning. The seven steps themselves include the following:

Step One - Identify Key Quality Indicators

Step Two - Validation of Key Quality Indicators

Step Three - Set Goals and Deployment Strategy

Step Four - Develop Assessment Strategies

Step Five - Set Baselines, Trends and Comparisons

Step Six - Benchmarking (Search for Better Practices)

Step Seven - Set Targets and Stretch Goals

By integrating this SSPP into all areas of the University, Northwest has been able to win the Missouri Quality Award in 1997 and 2001 (both times it was eligible) and has received a remarkable two-time site visit from the Malcolm Baldrige Quality Award examiners.

Therefore, this article is designed to set forth not only some of the assessment measurements that are used in the finance discipline, but the real nexus of the article is to show how these assessment measurements have been used as decision drivers to adjust and modernize course content and curricula.

Each discipline within my Department has their own unique SSPP. While many of the items may overlap, it also gives the flexibility needed to have a program process unique to that discipline as well.

\section{OUTCOMES ASSESSMENT}

Obviously, this overall planning process requires the use of all seven steps to be successful and even after you have gone through the process it is truly circular because you need to repeat the steps for further review and refinement to make sure everything in the plan is relevant and necessary to reach the next level of quality emphasis. 
However, in speaking around the country at professional meetings about our SSPP, it has become increasingly obvious that while most colleges and universities are doing outcome assessments to illustrate the quality of their programs, many times the information is gathered and never really used. In fact, in our Department (Accounting, Economics and Finance) I found in the first iteration of the SSPP that we were way "over-assessing" in hopes of learning about what alumni, employers and current students, our stakeholders, felt about our program and how we compared to others. Consequently, I did a thorough review of our Step Four on Development of Assessment Strategies and reduced our assessments to coincide more closely with our Key Quality Indicators and Departmental Goals. In short, if we were not going to use the feedback for our own assessment as a decision driver, we did not need the information. We had to look at what we "affectionately" called the "Goldilocks Syndrome" - too much, too little, or just right.

\section{ASSESSMENT INSTRUMENTS}

After the review was completed, what survived are the following assessment instruments:

Alumni Survey - a satisfaction survey to set forth how our alumni truly feel about their experience as a finance major at Northwest and opportunities for improvement (ofi's).

Employer Survey - Due to privacy issues, we had a poor response about how our Northwest grads were doing working for them, so this was redesigned to ask more what they were looking for in finance graduates in general, rather than our students in particular.

Major Field Achievement Test - a nationally normed exam testing a student's understanding of relevant business topics in eight business areas: accounting, economics, finance, management, marketing, international business, legal environment and quantitative analysis.

Professional Advisory Council - an annual meeting with a group of professionals from banking, investments, financial services, law, real estate and insurance.

Graduating Senior Survey - administered to all graduating finance majors by a trained graduate assistant based upon their overall satisfaction with their educational experience and for all finance courses specifically.

Business Faculty Survey - given to all business faculty bi-annually about the importance and their perceived relevance of all finance topics covered in all finance courses. This also lets them know not only what topics are being covered but gives them an opportunity to relate to us the potential of other finance topics that are relevant for their majors and/or courses.

\section{ASSESSMENT TARGETS}

In order to challenge ourselves for "continuous quality improvement," specific goals or targets were set for each of the assessment instruments to see how we actually "measured up":

Alumni Survey - At least $80 \%$ of the respondents self-reported they were very well prepared; well prepared; or prepared for their first employment experience. This is administered every three years to graduates from the past three years as a survey group.

Employer Survey - As previously mentioned, due to privacy issues we cannot ask about individual employees, we now use this as a target to continuously validate our existing Key Quality Indicators and our goals of the SSPP for the finance discipline in general - to make sure our graduates have what employers are looking for in a finance grad.

Major Field Achievement Test - Our target is to have at least $60 \%$ of all business students score at or above the national average in finance from all discipline areas. For our finance majors only, all finance students should score at the $90^{\text {th }}$ percentile in the finance category, and overall, $60 \%$ of our finance students should score above the national average on the other seven categories. 
Professional Advisory Council - will review different syllabi each annual meeting for relevance and discuss other "real world" topics. They also review outcomes from each assessment measure to see how we are performing. These, in turn, will help keep us current, meet employer and student needs and help continuous validation of our Key Quality Indicators and goals.

Graduating Senior Survey - to identify perceived relevance of all finance courses, usefulness of courses and if we are meeting our Key Quality Indicators as set forth on our SSPP. Our target is to have 2.0 or less, one being high - five being low, on both the relevance of our courses and the achievement of our KQIs.

Business Faculty Survey - administered to our business faculty to check topical coverage and relevance of all finance courses. The rating scale ranges from most important (1) to least important (5), with a goal to achieve a 2.50 or higher for the items taught.

\section{EXAMPLES OF USES OF OUTCOME MEASUREMENTS TO MODERNIZE CURRICULA}

Now that I have provided an overview of our "Culture of Quality," our Outcomes Strategy and our specific instruments and targets, what have we really done with all of this wonderful information that we have gathered?

\section{Less is More}

Through the feedback from our alumni survey, graduating senior survey and business faculty survey, it became clear that our students believed we were really trying to accomplish too much in our core Finance course known as fundamentals of finance. As we continued to add "essential" components to the class, no other material was deleted. Thus, the course got "too big for its own britches" and resulted in the lack of mastery or even understanding of truly important financial principles for all business students. Thus, the course was re-designed by the finance faculty to include only those concepts that, through our assessment input, professional meetings and readings, indicate that all business students should have.

This information remained at the heart of the course and through the redundancy teaching technique (which you now have time to do) students attained a much better comprehension (as shown in classroom performance and MFAT scores). The other "essential" items have been incorporated, where perceived to be necessary, into other finance courses for finance majors and a committee has been established to incorporate some of these knowledge skills into other "core" classes to not only cover the topics but to integrate them throughout the curriculum in a seamless fashion.

\section{Change in Major}

From the information generated in our outcomes measurements from our alumni survey, employer survey, graduating senior survey and professional advisory council, Northwest became (what I have at least been able to determine) the first University in the country to offer a three-option tract in the finance major area. They are: Financial Services, Financial Computing and Corporate Finance. As you can see from the figure below, the corporate finance is the most traditional of the finance options, while financial services mixes upper-division accounting courses with "core" finance classes and financial computing does the same with upper-division courses in computer science.

I know these changes would never have been done without the outcomes measurements information that we received and to date, we have seen a very positive feedback from each of these areas of "stakeholders."

\section{IMPROVEMENT IN NATIONAL TEST SCORES}

One other example I would like to share in this article is the use of our MFAT results and how those outcomes have once again influenced our curricula. What our results were showing us is that our finance majors were doing "over-the-top" performances on the nationally-normed MFAT test in the area of finance. This was fantastic (but somewhat expected, thank goodness)! 


\begin{tabular}{|c|c|c|c|c|c|}
\hline \multicolumn{2}{|l|}{ Option \#1 } & \multicolumn{2}{|l|}{ Option \#2 } & \multicolumn{2}{|l|}{ Option \#3 } \\
\hline \multicolumn{2}{|l|}{ Financial Services } & \multicolumn{2}{|l|}{ Financial Computing } & \multicolumn{2}{|l|}{ Corporate Finance } \\
\hline \multicolumn{2}{|l|}{ Required Courses } & \multicolumn{2}{|l|}{ Required Courses } & \multicolumn{2}{|l|}{ Required Courses } \\
\hline 51-303 Tax Accounting I & 3 & 53-325 Investment Principles & 3 & 53-325 Investment Principles & 3 \\
\hline $\begin{array}{l}\text { 52-352 Money, Credit \& } \\
\text { Banking }\end{array}$ & 3 & $\begin{array}{l}\text { 53-327 Intermediate Financial } \\
\text { Mgmt }\end{array}$ & 3 & $\begin{array}{l}\text { 53-327 Intermediate Financial } \\
\text { Mgmt }\end{array}$ & 3 \\
\hline 53-320 Insurance \& Risk & 3 & 53-420 Financial Institutions & 3 & 53-420 Financial Institutions & 3 \\
\hline 53-325 Investment Principles & 3 & 53-421 Selected Cases in Finance & 3 & 53-421 Selected Cases in Finance & 3 \\
\hline $\begin{array}{l}\text { 53-327 Intermediate Financial } \\
\text { Mgmt }\end{array}$ & 3 & \multicolumn{2}{|l|}{ Required Courses in CS/IS } & \multicolumn{2}{|l|}{ Required Courses in Accounting } \\
\hline 53-420 Financial Institutions & 3 & $\begin{array}{l}\text { 44-140 Intro to Prog Using Visual } \\
\text { Basic }\end{array}$ & 3 & 51-301 Cost Accounting & 3 \\
\hline $\begin{array}{l}\text { 53-421 Selected Cases in } \\
\text { Finance }\end{array}$ & 3 & 44-211 Spreadsheet Applications & 1 & 51-402 Advanced Cost Accounting & 3 \\
\hline Choose 3 hours from electives & 3 & $\begin{array}{l}\text { 44-212 Adv Spreadsheets \& } \\
\text { Charting }\end{array}$ & 1 & 51-306 Intermediate Accounting I & 3 \\
\hline 51-304 Tax Accounting II & & 44-346 Database Applications & 1 & $\begin{array}{l}\text { Approved Electives in Finance or } \\
\text { Acct }\end{array}$ & 3 \\
\hline 51-408 Managerial Accounting & & $\begin{array}{l}\text { 44-333 Multimedia \& Web } \\
\text { Development }\end{array}$ & 3 & & \\
\hline $\begin{array}{l}\text { 53-326 Investment } \\
\text { Management }\end{array}$ & & $\begin{array}{l}\text { Approved Electives in Finance or } \\
\text { CS/IS }\end{array}$ & 3 & & \\
\hline $\begin{array}{l}\text { 53-422 Real Estate } \\
\text { Management }\end{array}$ & & & & & \\
\hline Total Major Requirements & 24 & Total Major Requirements & 24 & Total Major Requirements & 24 \\
\hline
\end{tabular}

However, we also noticed that the management and marketing majors were not doing so well in the finance area. We understood that oftentimes the "mindsets" of these majors were much different than those in the finance and accounting areas where our "high-achievers" in the finance area were housed. But, in the interest of continuous quality improvement, we began to look at how we could use our outcomes information to develop a strategic plan for not only improving our scores, but to enhance these management and marketing student's learning and understanding of financial principles.

Thus, we encouraged the aforementioned inter-disciplinary committee to take a serious look at what we could do as a faculty to improve their all-important understanding of finance.

Some suggestions thus far have been: add an additional finance course to the "core" of business courses inasmuch as only the Fundamentals of Finance course is required and the coverage there has been purposely reduced; incorporate financial concepts into marketing and management courses as part of their overall curriculum reform; and in our required business capstone course, Organizational Policy and Decision Making, provide a "pre-test" at the beginning of the course with questions devised "in-house" by our faculty from each discipline to test the students general and overall understanding of the subject material. If a student shows a lack of basic understanding in the area, they shall be "required/encouraged" to get additional help in the form of tutoring and "concept overviews" prepared by the faculty, to improve their understanding of these basic concepts and tie a "post-test" directly to their grade in the course (to make it meaningful and worthwhile).

\section{CONCLUSION}

We continue to work at "continuous quality improvement." As you can see, we take those words very seriously. However, if you just assess for the sake of assessment, you are truly "missing-the-boat!" The real benefit of such is to not only better understand your own processes, but to use the information in a positive fashion that will improve the learning and understanding of the students we serve and to continue to update and modernize our curricula. That is our Passion! 